\title{
HUMBLE BUT PROUD: A COMPARATIVE CASE STUDY ON SOCIAL INNOVATION PRACTICES IN TURKEY
}

\author{
*Nihan Yıldırım \\ ** Olcay Bige Askun \\ *İstanbul Technical University \\ **Marmara University
}

\begin{abstract}
Social innovation (SI) is seen as an urgent alternative to technology-oriented innovation for solving global and local problems which have wide impact on all dimensions of PEST framework, because fundamental societal changes require a paradigm shift in our systems of innovation. While 2008 recession accelerated the research and practice on social innovation. Hence in most countries, practices are evolving for upgrading the social innovation capacity in all phases of innovation from idea generation to exploitation that leads to the rapid increase in social innovation economy. However, there is still a debate on the definition and coverage of social innovation and its practical dimensions. In Turkey, despite the existence of normatic, cultural and societal patterns that can enable social innovation practices, limited research is available on social innovation cases which can provide guidelines for new SI practitioners, and insights to the nature and characteristics of local social innovations to researchers. In this context, this paper aims to provide insights to dimensional and entrepreneurial characteristics SI Practices from Turkey in a comparative multiple case study framework. Findings reveal that despite their low "new-to-world" innovativeness and their limited contribution to structural changes or institutional arrangements, social innovation cases in Turkey involves high levels of social inclusion and strong Actor attributes together with effective usage of technology and community support.
\end{abstract}

Keywords: Social Innovation, Social Entrepreneurship, Case Study,

\section{INTRODUCTION}

The recent global 'economic crisis', is also instrumental for a shift towards SIs and perceived as gamechanging influence. The discourse of "crisis" has deeply penetrated public opinion and political discourses increasing the need for a fundamental solution (Avoline et al., 2014). The depression on the growth on the Gross Domestic Product (GDP), household incomes and employment (EC, 2013) and the growing recession have fuelled the perceptions of the global economic crisis. From a socio-technical perspective economic crises are recurring phenomena that somehow overlap with technological revolutions (Perez, 2013), as austerity policies reduce public spending on technologies, such as renewable energy, negatively impacting technological transitions (Geels, 2013). Corporate social responsibility (CSR) literature suggests CSR initiatives extend beyond meeting the immediate interests of stakeholders of for-profit enterprises, offering the potential to also enhance performance. Growing disillusionment of for-profit business models has drawn attention to social entrepreneurship and social innovation to ease social issues (Phillips et al., 2015).

In this context, this study presents the literature review on social innovation as a concept, motivations, enablers of social innovation, and also theoretical background on the dimensions of social innovation practices. Qualitative case analysis and comparative case analysis techniques are deployed for research. Findings and results are discussed for their implications and contributions to research base and future practices. 


\section{LITERATURE REVIEW AND THEORETICAL FRAMEWORK}

\section{Social Innovation Concept and Definitions}

Social innovation is a term which everyone likes but no one is sure about the meaning.” (Pol/Ville, 2009). "Social innovation concept had been adapted to various policy fields (development policy, research and development policy, innovation policy, employment policies, social policies etc.) and to various levels (local, regional, national and international) with different intentions, ideas and concepts. (Howaldt and et al., 2010). This is why, social innovation field is a multi-dimensional and multi-level concept due to its various practice fields, and gains new definitions and meanings upon the context of the perspective of the researchers and practitioners. Perceptions about the social innovation are different in India's rural areas, and in the South England as the social needs are significantly different than each other in these areas (Caulier-Grice, Davies, Patrick, Norman, 2012). On the other hand, most of the problems that are related to the definition of social innovation is caused by the fact that social innovation practices hardly combines the social and innovative characteristics (European Union/The Young Foundation, 2010). Innovation requires newness in terms of user, context, or practice that can cause sustainable development and progress by introducing a solution which is more effective and efficient solution than its existing alternatives. Here, the sustainability refers to continuity in long run and sustainability in both organizational and environmental context. (Phills Jr., Deiglmeier, Miller, 2008). Apart from all these debates on the definition of social innovation, there is a strong consensus on the benefits of social innovation for transformational change that is required for solving social and environmental problems in local (like building a gardening habitat in a neighborhood) and global (like global climate change or preventing poverty) context.( Goldenberg, et al. Social Innovation in Canada: An Update, CPRN Research Report). It is widely accepted that conventional industries, life styles and current structures of multinational institutions can not anymore sustain themselves and cannot solve critical survival problems of earth and its communities in their current forms, which recalls for new social economy (R.Murray, Danger and opportunity Crisis and the new social economy, 2009)

2008 recession accelerated the research and practice on social innovation. Hence in most countries, practices are evolving for upgrading the social innovation capacity in all phases of innovation from idea generation to exploitation that leads to the rapid increase in social innovation economy (Murray, 2009, s.5). On the other hand, social innovation is not a concept that is dedicated to non-profit economy. It involves and comes out with the efforts of public sector, governments (like new models in public health), markets (like open source software or organic food), movements (fair trade), academia (like pedagogical models in child care), and social entrepreneurs (like micro credits). Most of the successful social innovators had learned to move across the borders between these sectors; which means that the best social innovations occurred when small organizations or entrepreneurs (which can be called as moving, fast bees) and large organizations which can grow these ideas (which can be called as big trees with strong roots) collaborated in an effective way (Mulgan, et al. 2007). The old paradigm of "state help" remains insufficient in this context and it is replaced by innovative solution that can feed sustainable growth, job security and competitive skills (Urama,et al., 2013).

Social innovation is not only the search for satisfaction of social needs caused by the absence of the Government or the Market, but also it is an opportunity to find answers to multiple social, an economic and environmental crisis. Therefore, civil society organizations try to react and search for new practices through social innovation initiatives, by using local solidarity and reciprocity mechanisms that recognize new governance structures (Pisano, Lange, \& Berger, 2015).

Social innovations are assessed as complimentary to technological innovations in the organizational settings (i.e. Freeman, 1988; Schumpeter, 1934; Drucker, 1985). However, in the last decades, Social innovation had been defined in various ways as:

-Any new approach, practice, intervention, or product elaborated to improve a social situation or solve a social problem (Bouchard 1999)

-Finding concrete ways to deal with social and economic problems so as to make a real difference in the lives of real people (Goldenberg, 2004) 
-Changes in social relations, especially with regard to governance, that enable the above satisfaction, but also increase the level of participation of all but especially deprived groups in society“(Moulaert, 2005)

-An intended change in social practices that in some way or another contributes to overcoming concrete social problems and/or to satisfying the needs of specific societal actors.” (Howaldt \& Schwarz 2010)

-Innovative activities and services that are motivated by the goal of meeting a social need and that are predominantly diffused through organizations whose primary purposes are social (Mulgan, 2006)

-A novel solution to a social problem that is more effective, efficient, sustainable, or just than existing solutions and for which the value created accrues primarily to society as a whole rather than private individuals." (Phills et al. 2008).

-The development and implementation of new ideas (products, services and models) to meet social needs and create new social relationships or collaborations; new responses to pressing social demands, which affect the process of social interactions or innovations that are social in both their ends and their means, that are not only good for society but also enhance individuals' capacity to act (EC, 2013).

"Goldenberg (2004) defines SI as "finding concrete ways to deal with social and economic problems so as to make a real difference in the lives of real people”, underlining the concrete nature of SI in designing real solutions. Focusing on governance, marginalization and participation, Moulaert et al., (2005) suggested SI as "changes in social relations, especially with regard to governance, that enable the above satisfaction, but also increase the level of participation of all but especially deprived groups in society". Similarly, Harrison \& Vezina (2006) emphasized "the coordination of relationships among social actors in the solving of socio-economic problems, with the goal of improving the performance and the wellbeing of communities” in their definition of SI. Martinelli (2012) described SI as contributing to the satisfaction of human needs that are otherwise be ignored, contributing to the empowerment of (marginalized) individuals of groups and contributing to the changes in social relations (p.172). Mulgan (2006), on the other hand, focused on set of "innovative activities and services that are motivated by the goal of meeting a social need and that are predominantly diffused through organizations whose primary purposes are social”, turning our ontology towards activities, processes and practices in understanding SI. Whereas Phills et al. (2008) focused on where and when the value is created and defined SI as "a novel solution to a social problem that is more effective, efficient, sustainable, or just than existing solutions and for which the value created accrues primarily to society as a whole rather than private individuals" (cited in Hubert et al., 2010).

\section{Approaches to Social Innovation}

According to European Commission (2013): social innovation approaches are:

-Open rather than closed when it comes to knowledge-sharing and the ownership of knowledge;

-Multi-disciplinary and more integrated to problem solving than the single department or single profession solutions of the past;

-Participative and empowering of citizens and users rather than 'top down' and expert-led.

-Demand-led rather than supply-driven;

-Tailored rather than mass-produced, as most solutions have to be adapted to local circumstances and personalized to individuals.

Integrated problem solving approach can be discussed for supporting expanded reproduction.

In social innovation context three sectors of society - civil society, public and private - has its own internal logic of action and defining features. Taken together, these three ideal-type sectors can be conceptualized as a triad represented in stability as a triangle, where between each points lies a spectrum of hybrid institutions and organizations that represent sites for social innovation as a boundary-blurring activity (Nicholls et al., 2015). 


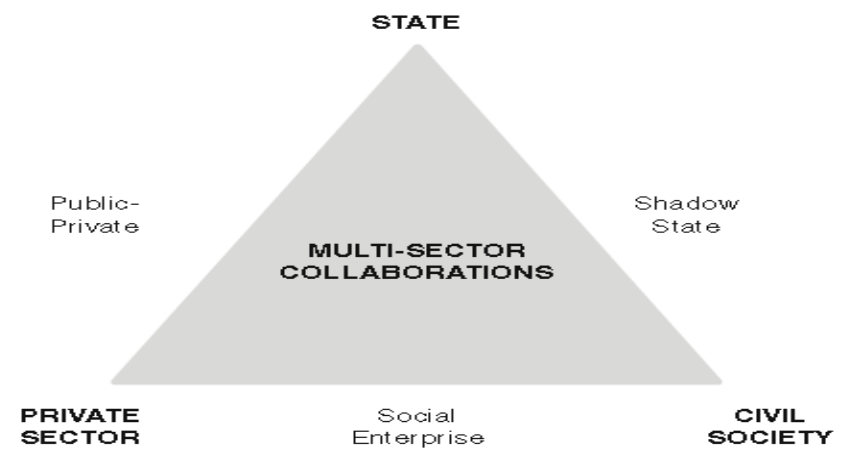

Figure 1. The social innovation triad (Nicholls and Murdock (2012).

For classifying the levels and dimensions of social innovation, Nicholls and Murdock (2012) provided two frameworks that utilizes the result/impact levels (Table 1) and the context/scope which the social innovations processed and had impact (Table 2).

Table 1 Levels of social innovation Nicholls and Murdock (2012)

\begin{tabular}{|c|c|c|}
\hline Level & Objective Focus & Examples \\
\hline Incremental & To address identified market failures more effectively & $\begin{array}{c}\text { Products Kickstart (low-cost } \\
\text { irrigation foot pump) }\end{array}$ \\
\hline Institutional & To reconfigure existing market structures and patterns & Markets M-PESA (mobile banking) \\
\hline Disruptive & $\begin{array}{c}\text { To change cognitive frames of reference to alter social } \\
\text { systems and structures }\end{array}$ & Politics Tostan (human rights) \\
\hline
\end{tabular}

Table 2 Dimensions of social innovation Source: Nicholls and Murdock (2012)

\begin{tabular}{|c|c|c|}
\hline Dimension & Social process & Social outcome \\
\hline Individual & Co-Production(Southwark Circle) & Lost-cost Healthcare (Aravind Eye Hospital) \\
\hline Organisation & Wiki-Production (Wikipedia) & Work Integration Social Enterprise (Greyston Bakery \\
\hline Network/Movement & Open Source Technology (Linux) & $\begin{array}{c}\text { Non-Traditional Training and Education (Barefoot } \\
\text { College) }\end{array}$ \\
\hline System & Microfinance (Grameen Bank) & Mobile Banking (MPESA) \\
\hline
\end{tabular}

\section{Perspectives of Social Innovation: Processes and Results}

As (Correia et al., 2017) stated, concepts of social innovation integrate two perspectives that are processes and results (Sharra \& Nyssens, 2010; Hulgård \& Ferrarini, 2010).

Process perspective includes (1) inclusion, (2) capacitation, and (3) intense cooperation between the actors involved (Lassance \& Pedreira, 2004; André \& Abreu, 2006; Bignetti, 2011). Process perspective has an emphasis on the participatory and collaborative nature of learning (Nilsson, 2003; Lassance \& Pedreira, 2004; André \& Abreu, 2006; Klein, Tremblay, \& Bussiéres, 2010; Young, 2011).

The result's perspective considers that social innovation needs to go beyond specific needs, aiming for social value, based on values, aspirations and creation of new meanings (Saucier et al., 2006; Mulgan, 2007; Phills et al., 2008; Howaldt \& Schwarz, 2010; Assogba, 2010)

For this integrated approach, the product of social innovation cannot be isolated from the process or the way how innovation was organized and developed (Correia et al., 2017). Based on the concept adopted for social innovation and on the review of its characteristics, a number of social innovation's dimensions of analysis compose this paper's framework and are categorized in 1. Actors; 2. Processes and collective activities; 3. Social needs; 4. Social improvements or answers; 5. Innovativeness. 
Journal of Global Strategic Management | V. 11 | N. 2 | 2017-December | isma.info | 077-100 | DOI: 10.20460/JGSM.2018.254 Table 3 Dimensions of Social Innovation (Correia et al., 2017).

\begin{tabular}{|c|c|c|c|}
\hline $\mathrm{Nr}$ & Dimension & Definition & Success Factors \\
\hline 1 & Actors & $\begin{array}{l}\text { social organizations and institutions (Tardif \& Harrisson, 2005) } \\
\text { members/individuals of the civil society, of cooperatives and } \\
\text { associations, of unions or community associations; companies, } \\
\text { social economy organizations, collective enterprises, and } \\
\text { beneficiaries of private organizations; institutional actors the State } \\
\text { representatives' in the three levels (federal, state and local). }\end{array}$ & $\begin{array}{l}\text { synergy of actors } \\
\text { motivation for innovation; } \\
\text { strength to deal with obstacles; } \\
\text { availability to manage the resources to fix } \\
\text { those obstacles } \\
\text { (Tardif \& Harrisson, 2005) }\end{array}$ \\
\hline 2 & $\begin{array}{l}\text { Processes and } \\
\text { collective } \\
\text { activities }\end{array}$ & $\begin{array}{l}\text { creation and implementation process: the diversity of actors and } \\
\text { the user's participation (Cloutier, 2003). } \\
\text { all phases of the social innovation process: } \\
\text { from problem awareness to identification of causes and } \\
\text { implementation of solutions. } \\
\text { interdisciplinary team, introduction of new assignments, a new } \\
\text { division of labor based on aptitude and interests, new coordination } \\
\text { and learning methods to improve practices (Cloutier, 2003; Tardif } \\
\text { \& Harrisson, 2005; Cunha\& Benneworth, 2015). }\end{array}$ & $\begin{array}{l}\text { cooperation between the actors } \\
\text { active participation of } \\
\text { individuals/organizations that represent this } \\
\text { dimension } \\
\text { social inclusion, } \\
\text { training individuals and } \\
\text { the idea of social change as a factor that can } \\
\text { transform the relations of power (André \& } \\
\text { Abreu, 2006). }\end{array}$ \\
\hline 3 & Social needs & $\begin{array}{l}\text { co-constructions made by civil society, in a bottom-up and } \\
\text { democratic process. how SI objectives will be defined and built by } \\
\text { civil society, to be put into practice, and the purpose of that } \\
\text { innovation should be qualified as socially innovating ( Besançon } \\
\text { \& Guyon 2013). }\end{array}$ & $\begin{array}{l}\text { Actors role in identifying social needs, to } \\
\text { help to solve social claims that are not } \\
\text { articulated with necessities and to cooperate } \\
\text { with actors and affected parties during the } \\
\text { data collection phase. structural } \\
\text { modifications that occur due to the search } \\
\text { for social needs satisfaction, and those needs } \\
\text { can be qualified as incremental, radical or } \\
\text { systemic (Mulgan, 2006). }\end{array}$ \\
\hline 4 & $\begin{array}{l}\text { Social } \\
\text { improvements } \\
\text { or answers }\end{array}$ & $\begin{array}{l}\text { systemic change phase as the final objective of social } \\
\text { innovation; Cloutier (2003) } \\
\text { focus on social objectives, directing their efforts towards the less } \\
\text { fortunate or marginalized sectors of society. } \\
\text { civil society can (re)discover its cooperation power and become an } \\
\text { active agent in the search for solutions of local social needs. This } \\
\text { process is favoured when its members creatively use products, } \\
\text { services, places, knowledges, abilities and existing traditions } \\
\text { (Manzini, 2014), while managing their own resources, without } \\
\text { waiting for a general top-down change in politics, economics, } \\
\text { institutional assets and system infrastructure. }\end{array}$ & $\begin{array}{l}\text { More effective than existing solutions } \\
\text { generate improvements in terms of results, } \\
\text { including living conditions, satisfaction } \\
\text { levels, life expectancy rates, reintegration } \\
\text { into the labor market, improving welfare and } \\
\text { social cohesion (Westley, 2008; Organisation } \\
\text { for Economic Co-operation and } \\
\text { Development, 2010; Caulier-Grice et al., } \\
\text { 2012) } \\
\text { intends to do more than to just solve a social } \\
\text { issue, intends to provide answers to an } \\
\text { aspiration (Saucier et al., 2006; Sandeep \& } \\
\text { Ravishankar, 2015). }\end{array}$ \\
\hline 5 & Innovativeness. & $\begin{array}{l}\text { one action of reorganization measured by the extension and depth } \\
\text { of changes caused on the environment (Cloutier, 2003) } \\
\text { determined problematic situation. These solutions must be "new", } \\
\text { unprecedented in the environment in which they emerge, being } \\
\text { also identified as the implementation of new institutional } \\
\text { arrangements between actors and new social rules (Tardif \& } \\
\text { Harrisson, 2005). } \\
\text { The impact of the innovation is a more determinant trait for social } \\
\text { innovation than its novelty factor. However, new solutions serve } \\
\text { to assist in achieving results, improving existing practices and } \\
\text { consequently improving the lives of populations (Caulier-Grice et } \\
\text { al., 2012). } \\
\text { to allow innovation that has already been used in another context, } \\
\text { nonetheless, what characterizes social innovation is a new } \\
\text { institutional arrangement provoked by a collective action }\end{array}$ & $\begin{array}{l}\text { implementation of new institutional } \\
\text { arrangements between actors and new social } \\
\text { rules } \\
\text { New solutions emerge as alternatives in the } \\
\text { implementation's initial phase, however, in } \\
\text { long-term, tend to be institutionalized, } \\
\text { generating new work, development, and } \\
\text { governance models. } \\
\text { innovative character of the innovation } \\
\text { process, from the identification of social } \\
\text { needs to the implementation process, as well } \\
\text { as the adaptation to other contexts at the } \\
\text { time of reapplication. All of this } \\
\text { development depends on the participation of } \\
\text { a diversity of actors who act in a democratic } \\
\text { fashion, }\end{array}$ \\
\hline
\end{tabular}


In this study, above given dimensions that were introduced by Correia et al. (2017) are utilized for analyzing the social innovation cases from Turkey in a comparative manner.

\section{Social Innovation Outlook for Turkey}

As a rapidly developing country and the largest national economy in Central and Eastern Europe, Turkey's economic climate offers a complex environment for innovators with a large increase in the active working population, but a very modest rise in the demand for labour. Problems such as underemployment, an unqualified young population and the growth of the informal sector certainly exist, but their solution seems a long way off due to internal and external economic conditions. Despite obstacles posed by the economic climate and political situation, social innovators in Turkey are working to address a range of social problems about education, the deepening income differences between social classes, unemployment and a traditionally marginalizing approach to disabled people who constitute $12 \%$ of the population. Further, social innovators in Turkey are alert to the approaching issues generated by an aging population. Although people over the age of 65 currently account for only 7.2 percent of the total, this number is due to grow dramatically. With the decreasing birth rate and increasing life expectancy, Turkey — a relatively young country — will soon have to face the issues of an aging population (Sözen and Tutal, 2016).

Social innovation has recently gained popularity in Turkey, mostly due to the support of a limited number of NGOs and private sector organizations. In Turkey, social projects are mainly supported by NGOs, foundations and a majority of private sector organizations which allocate budget for social innovations and social projects. As well Academia/Universities are among the major actors in social innovation. Social innovations require ecosystems for creating added value in local context, which can be seen as derivations from Etzkowitz's (2002) Triple Helix Model (Academia-Government-Industry Collaboration) where government acts as an enabler of an effective collaboration platform and provider of support and incentives, while universities and social industry and communities serve to create knowledge and apply it to social problems (Yıldırım, 2016). In Turkey, social innovation ecosystems are still immature, however there are significant increase in the quantity and quality of actors that serve social innovation like NGOs (TUSEV, STGM), private sector institutions (ABSAM|SASIM, Mikado, SIM) and structures in universities (Koç University Social Impact Forum, Sabancı University Social Investment Forum, Bilgi University Social Incubation Center etc.) (Yıldırım, 2016). There is still room for improvement in terms of supports from government, priorities from private sector (like going beyond social corporate responsibility score focused projects) and also from technology incubators, local authorities and citizens.

\section{RESEARCH METHOD}

\section{Sample and Data Collection}

The survey of this study is conducted on total 10 case studies on Social Innovation Practices from Turkey between 2010-2017. We conducted a document and content analysis in the informing websites of these projects/products, searched through the news about them that took place in digital media and interviewed with the users or customers of these projects.(Here document analysis refers to "systematic analysis of the content of relevant documents for research and evaluation purposes" (Goodrick, 2014).

As Yin (2002) stated, case study is a preferred strategy when "how" and "why" questions are posed and investigator has little control over events also when the focus is on a contemporary phenomenon within some real-life context. Our case is a comparative multiple case study (Yin, 2002) that matches with these circumstances as the dimensions of social innovation in the studied Social Innovation Practices/projects/products are evident; common and unique aspects of these social innovation cases. actual motivations and ways of improvement in the company needed to be tied to a theoretical framework. As Goodrick (2014) concluded on comparative case studies:

"Comparative case studies cover two or more cases in a way that produces more generalizable knowledge about causal questions (Goodrick, 2014). Comparative case studies are undertaken over time and emphasize comparison within and across contexts. Comparative case studies may be selected when it is not feasible to undertake an experimental design and/or when there is a need to understand and explain how features within the context influence the success of programme or policy initiatives. Comparative 
case studies involve the analysis and synthesis of the similarities, differences and patterns across two or more cases that share a common focus or goal... Comparative case studies are utilized ... when an understanding of the context is seen as being important in understanding the success or failure of the intervention."

Cases are selected with a developing country perspective that focuses on development, hence study covered social innovation practices that are related to urbanization, inequality, poverty, democratization problems rather than political problems like environmental/climate change, immigration, aging, unemployment (as these require inclusion of government agencies, public institutions, municipalities, research institutions which all are critical actors in these problematic themes.). Additionally, to avoid political debates and information sharing limitations, civil SI practices are selected rather than the ones that are partnered or supported by governmental or public institutions.

In this study, social innovation projects and practices are analyzed in terms of the dimensions that were introduced by Correia et al. (2017) for their similarities, differences and patterns. The following dimensions are used as the first part of Key Evaluation Questions: 1. Actors; 2. Processes and collective activities; 3. Social needs; 4. Social improvements or answers; 5. Innovativeness.

Additional Key Evaluation Questions are set as "History of the project, Whether they are incubated in a accelerator or incubation center of innovation $(\mathrm{Y} / \mathrm{N})$, If they are proposed and developed and deployed by Private Sector / Industry domination or not, Whether they received investment or not, The owner or performers of the project".

During the case study data collection and analyses, following steps are taken (referring to steps of implementation of Goodrick 2014):

Key Evaluation Questions are clarified and these are derived from the literature (SI dimensions from Correia et al., 2017, SI Process perspectives on inclusion, participatory approach and intense cooperation between actors from (Lassance \& Pedreira, 2004; André \& Abreu, 2006; Bignetti, 2011; Nilsson, 2003; ecosystems from Yildirim, 2016).

Following hypotheses are proposed based on the theoretical background that is presented in Literature Review section.

Type of cases are defined (representing a diverse examples of social problems from different contexts All problems were social, they evolved in time by the occurrence of new trends in capitalist markets, technological developments, changes in supply chain and logistics, immigration from rural areas to urban areas, financial recessions and political instability. They could not be solved by regulative or industrial current solutions and approaches.

Document analysis, web content analysis, media analysis are identified as the methods how evidence will be collected within and across cases

\section{ANALYSIS AND FINDINGS}

In the light of the literature review, paper discuses the similarities and differences of social innovation practices to support or refute propositions as to why they succeeded or failed. That is how we proposed the following hypotheses:

\section{H1: Actors became determinant in Success of Social innovations in Turkey}

\section{H2: Processes and collective action became determinant in Success of Social innovations in Turkey .}

H3: Private sector support and investments, incubations became determinant in Success of Social innovations in Turkey

H4: Innovativeness level (in global scale) became determinant in Success of Social innovations in Turkey

By the dimensions derived from Table 3, (Dimensions of Social Innovation (Correia et al., 2017) somparisons of these projects as multiple case studies are represented in Table 4. As well comparative analysis of the cases by entrepreneurial characteristics are given in Table 5 below. Case studies are presented in the following section, ending with comparative analysis of cases. 


\section{$O Y$ and Beyond (founded in 2014)}

Problem definition : lack of transparency in elections, problems about democratization

Results: Success - 30,000 volunteersi effective monitoring in two elections

\begin{tabular}{|c|c|}
\hline Dimensions & Explanations \\
\hline Actors & $\begin{array}{l}\text { It was founded by apolitic } 8 \text { young friends who founded on April 24, } 2014 \text { and wanted to channel a } \\
\text { civilian project in central Istanbul. } \\
30000 \text { volunteers in } 2014 \text { and then reached } 50000\end{array}$ \\
\hline $\begin{array}{l}\text { Processes and } \\
\text { collective } \\
\text { activities }\end{array}$ & $\begin{array}{l}\text { We have determined our OUR STUDIES in } 3 \text { different areas where we will continue our mission to } \\
\text { contribute to the future for the better days we will spend in our country beyond "having our voice." (1) } \\
\text { expanding and activating our volunteer polling observer organization, (2) being a pressure group for } \\
\text { eliminating defects in the electoral system, and finally (3) realizing our efforts to strengthen our social } \\
\text { network. } \\
\text { providing financial and spiritual support and allowing the Voting and Beyond to turn into a long-lasting } \\
\text { and much more active action. As our members, we will take our decisions together with you in our } \\
\text { general assembly and we will act together on the basis of our principles. } \\
\text { To make projects for the settlement of participatory democracy in Turkey. In doing so, by bringing } \\
\text { together people with different beliefs and views from different parts of the society, contributing to the } \\
\text { integrity of society by providing a suitable environment for them to work together for one purpose. }\end{array}$ \\
\hline Social needs & $\begin{array}{l}\text { ' to protect our vote". Some incidents were reported in previous elections in Turkey. Vote protection } \\
\text { became a major issue for some citizens in } 2014 \text { elections }\end{array}$ \\
\hline $\begin{array}{l}\text { Social } \\
\text { improvements } \\
\text { or answers }\end{array}$ & $\begin{array}{l}\text { To make projects for the settlement of participatory democracy in Turkey. In doing so, by bringing } \\
\text { together people with different beliefs and views from different parts of the society, contributing to the } \\
\text { integrity of society by providing a suitable environment for them to work together for one purpose. } \\
\text { 1. The establishment of participatory democracy consciousness in Turkey, participation in elections and } \\
\text { elections broadcast and research in real and virtual environments with the aim of supporting make, } \\
\text { organize symposiums, meetings, conferences, discussions } \\
\text { 2. Using scientific and objective methods for environmental and social problems to try to produce liberal, } \\
\text { egalitarian, fair, sustainable and permanent solutions } \\
\text { 3. The protection of individual freedoms through organized events, the rule of law, judicial } \\
\text { independence, separation of powers, freedom of the press, transparent and accountable management } \\
\text { contributing to the passing of the building blocks of democracy } \\
\text { 4. Contributing to the establishment of an effective understanding of local government working with the } \\
\text { community to develop projects for the improvement of local policies, to helping to produce a systematic } \\
\text { solution, electoral-elected intercollegiate contributing to the strengthening of citizenship, developing } \\
\text { citizenship awareness and constitutional democratic to promote the dissemination of information on } \\
\text { rights; } \\
\text { 5. The successful completion of Turkey's accession process to the European Union (EU) Conformity to } \\
\text { the Copenhagen political criteria - in the framework of our country, the creation of an institutionalized } \\
\text { democracy, the rule of law and the rule of law and to organize activities in this context; } \\
\text { 6. To carry out studies in the fields of social and cultural education, to ensure the activation and } \\
\text { development of their activities and to to work with people and organizations who have to provide } \\
\text { assistance and solidarity among the social sections, to promote social development undertake initiatives } \\
\text { to make young people and women more active in their fields }\end{array}$ \\
\hline Innovativeness & $\begin{array}{l}\text { Highly innovative globally, and locally . New models of interaction were introduced and designed. IT } \\
\text { infrastructure is estahlished for vote monitoring and counting. } \\
\text { Trainings were given to volunteers. } \\
\text { Processes are designed uniquely for Turkey's election system processes. } \\
\text { As a model, the solution is applicable to other contexts . Organizing ways and communication channels } \\
\text { can be replicated, while processes should be adapted in each case. }\end{array}$ \\
\hline
\end{tabular}




\section{Needs Map-ihtiyacharitasi.org (founded in 2015)}

Problem definition: poverty, education and lack of financing mexhanisms for underprivileged regions and individuals

Results: Success - More than 20 need / donation matching campaigns and projecte were completed by Fall 2017. There are thousands of subscribers from all regions.

\begin{tabular}{|c|c|}
\hline Dimensions & Explanations \\
\hline Actors & $\begin{array}{l}\text { Mert Firat (celebrity, actor, activist) founder } \\
\text { The team for Technological Solution } \\
\text { School teachers and administrators } \\
\text { NGO and foundations for sharing and collaboration between citizens } \\
\text { Volunteers } \\
\text { Sponsors and contributors, (Private sector social responsibility foundation ) } \\
\text { Other NGOs } \\
\text { Culture and art initiatives } \\
\text { habitat }\end{array}$ \\
\hline $\begin{array}{c}\text { Processes and } \\
\text { collective } \\
\text { activities }\end{array}$ & $\begin{array}{l}\text { The purpose of the Needs Map is to systematically learn the needs of citizens on the basis of city and } \\
\text { neighborhood in Turkey, to collect them on a map basis and to create a system for facilitating meeting } \\
\text { these needs with the necessary institutions / organizations or private persons. It is also a digital platform } \\
\text { where not only the needy but also the people or institutions who want to support in different issues can } \\
\text { enter the support of the map base again and those who need it can benefit from these supports. } \\
\text { Need In: In this section, you can find the places you live (street, neighborhood, city, village, school ...) } \\
\text { education, health, transportation etc. you enter your needs as address-based. In this section, the owner (ie } \\
\text { you) is asked to share contact information, what you need, what you need, and if you have a photo. You } \\
\text { need to be a member to your web site to get it. After you become a member, you can enter your profile } \\
\text { in detail. After that, you can see what you need in the map on the main page as short information. } \\
\text { Anyone who wants to meet your needs with this information that is openly available can meet your } \\
\text { needs by pressing the "I want to meet the need" section. In this process, we do not share your } \\
\text { information with the 3rd person or parties unless you want your information. That's why we have a } \\
\text { reliable and effective filtering process. } \\
\text { For example; your primary school in your neighborhood needs musical instruments, what can you do? In } \\
\text { this regard, you need to visit our map online and specify the place where the school is located on the } \\
\text { map, and then you will be in need of detailed information on the form that is not available. You leave } \\
\text { this form and the contact information you need. Those who want to meet your needs can contact you } \\
\text { from here. In this process, we also support you to meet your needs as needed }\end{array}$ \\
\hline Social needs & $\begin{array}{l}\text { Need owners and donors/helpers match } \\
\text { A database and a map that shows the routine social needs that can be solved by donations of citizens and } \\
\text { organizations. A system for facilitating meeting these needs with the necessary institutions / } \\
\text { organizations or private persons } \\
\text { Whenever we live, we know that we always need to have things to live. The fulfillment of these needs is } \\
\text { the duty of both social responsibility consciousness and citizens as well as related institutions. } \\
\text { These needs are distributed and not organized, so donors or volunteers can not systematically follow up } \\
\text { the needs in the country. }\end{array}$ \\
\hline $\begin{array}{c}\text { Social } \\
\text { improvements } \\
\text { or answers }\end{array}$ & 20 different needs from different regions of Turkey were met through this application. \\
\hline Innovativeness & $\begin{array}{l}\text { This organization is the first online digital platform to meet this need with the needy persons in Turkey. } \\
\text { İnnovative for its integration capability, locally, but not globally }\end{array}$ \\
\hline
\end{tabular}




\section{Acik Radyo - Open Radio (founded in 1995)}

Problem definition : standardized and capitalized media with profit focus and without education and cultural development aims

Results: Success - Actively operating for 10 years, with thousands of volunteers and donors, cooperate sponsors with almost $20 \mathrm{~K}$ listeners.

\begin{tabular}{|c|c|}
\hline Dimensions & Explanations \\
\hline Actors & $\begin{array}{l}\text { A collective, which has } 62 \text { partners holding almost equal shares with the shareholders owning "share } \\
\text { certificates", } \\
\text { Individuals from more than } 22 \text { different nationalities of the world -American, Belgian, Bosnian, } \\
\text { Brasilian, British, Bulgarian, Canadian, Costa Rican, Dominican, French, German, Greek, Iranian, } \\
\text { Israeli, Italian, Lebanese, Russian, Spanish, Sudanese, Turkish, etc. } \\
\text { Corporations as sponsors } \\
\text { Listeners as supporters (financial and operational content) } \\
\text { Cultural and art foundations }\end{array}$ \\
\hline $\begin{array}{l}\text { Processes and } \\
\text { collective } \\
\text { activities }\end{array}$ & $\begin{array}{l}\text { During Açık Radyo's } 22 \text { years of broadcasting some } 1100 \text { original programs have been produced and } \\
\text { broadcast by a record number of nearly } 1200 \text { individuals... } \\
\text { It must be stressed primarily that Açı Radyo is not dependent on any interest group or any capital } \\
\text { group. Needless to say, it is completely independent from the state, too. The radio station is only } \\
\text { dependent on the principles of pluralist democracy, the rule of law, and the protection and promotion of } \\
\text { universal human rights and fundamental freedoms. Thus, it is an independent medium. It can be } \\
\text { considered as one of the rare independent institutions in the Turkish media scene, which is under } \\
\text { increasing pressure from both the state and from the concentration of ownership of financial and power } \\
\text { centers. }\end{array}$ \\
\hline Social needs & $\begin{array}{l}\text { Independent media - broadcasting from any interest group or any capital group, protecting and } \\
\text { advocating the principles of pluralist democracy, the rule of law, and the protection and promotion of } \\
\text { universal human rights and fundamental freedoms. }\end{array}$ \\
\hline $\begin{array}{l}\text { Social } \\
\text { improvements } \\
\text { or answers }\end{array}$ & $\begin{array}{l}\text { During its } 22 \text { years of existence Açık Radyo has called upon the talents and efforts of } 1210 \text { individuals - } \\
\text { ages ranging from } 9 \text { to } 75 \text { - from all walks of life and from a rich variety of professions -as well as those } \\
\text { of a few unemployed- who contributed with more than } 1083 \text { programs (talk "shows", music "shows", } \\
\text { etc.) to the radio station. } \\
\text { Currently, } 211 \text { programmers contributes with more than } 144 \text { different programs to Açı Radyo each } \\
\text { week. } \\
\text { Funded by listeners and sponsors. } \\
\text { Proved that independent broadcasting is possible. Provided unique and participatory, inclusive content to } \\
\text { society. }\end{array}$ \\
\hline $\begin{array}{l}\text { Innovativenes } \\
\text { s }\end{array}$ & $\begin{array}{l}\text { Locally innovative, first open source radio station in Turkey } \\
\text { Unique for its structure and funding model and also its content creation in global scale }\end{array}$ \\
\hline
\end{tabular}




\section{Another Cinema - Başka Sinema (founded in 2013)}

Problem definition: Market/profit focused movie distribution chains, lacking support for art/culture products

Results: Success - Spread to 6 cities and 16 cinema theaters in 1 year, Facebook 144.000 followers; Twitter 44.000 followers, Became a column in Variety magazine in 2014. Another Cinema films packed theaters at an average 60\%-70\% capacity, much higher than the average $15 \%-20 \%$ capacity in theaters with mainstream fare. http://variety.com/2014/film/global/a-new-distribution-model-gives-turkeys-film-fans-their-fill-offoreign-fare-1201066391/

\begin{tabular}{|c|c|}
\hline Dimensions & Explanations \\
\hline Actors & $\begin{array}{l}\text { Founders: M3 Film and Kario \& Ababay } \\
\text { Cinema distribution chains. } \\
\text { Independent Film Makers } \\
\text { Movie Festival Audience who are interested or fan for independent art films and documentaries }\end{array}$ \\
\hline $\begin{array}{l}\text { Processes and } \\
\text { collective } \\
\text { activities }\end{array}$ & $\begin{array}{l}\text { The independence of the festivals movies all year round with the same interest and enthusiasm to be } \\
\text { watched. All the excitement of the festival spread } \\
\text { Favorite on national and international platforms winner but entering the vision in Turkey creating } \\
\text { challenging films in Turkey. } \\
\text { Out of the routine cinematic experience, Film makers and distribution channels works collectively. } \\
\text { By combining movie shows and events, in constant communication and interaction with the audience } \\
\text { stay. Also in line with the viewer's wishes to create a flexible structure that can be shaped. Flexibility of } \\
\text { the programming is the strength } \\
\text { Especially young film directors and bringing them together with the actors. } \\
\text { Cinebaby Sinebebe enabiles mothers to watch films with their babies. } \\
\text { Participation of the watchers/audience is critical and enabled by the model } \\
\text { An aggressive campaign in the local press and on social media have fostered awareness, but attendance is } \\
\text { the most convincing marker of its success. Another Cinema films have been packing theaters at an } \\
\text { average } 60 \%-70 \% \text { capacity, much higher than the average } 15 \%-20 \% \text { capacity in theaters with } \\
\text { mainstream fare. }\end{array}$ \\
\hline Social needs & $\begin{array}{l}\text { Rigid and market/profit focused schedules and operation models of current cinema theater chains. } \\
\text { The Turkish exhibition sector operates on a unique model that favors Hollywood and local hits, since } \\
\text { films that don't perform well in their first week are pulled. When a screening slot opens up in a theater, } \\
\text { an arthouse distrib will take it, often at the last minute, giving little time for advertising or marketing - } \\
\text { thus guaranteeing that the first week's box office won't be strong, and the film will be replaced. } \\
\text { No room for independent and art films, documentaries in these theaters, or too limited time or capacity } \\
\text { allocated to those. Inability of independent film makers to find theaters and make their films shown to } \\
\text { audience with low cost. Dependency to oligopolistc distribution and operation models in cinema business }\end{array}$ \\
\hline $\begin{array}{l}\text { Social } \\
\text { improvements } \\
\text { or answers }\end{array}$ & $\begin{array}{l}\text { The independence of the festivals movies all year round with the same interest and enthusiasm to be } \\
\text { watched. All the excitement of the festival spread } \\
\text { Favorite on national and international platforms winner but entering the vision in Turkey creating } \\
\text { challenging films in Turkey. } \\
\text { movies are longer with a more flexible program to remain in the vision for a while. }\end{array}$ \\
\hline Innovativeness & $\begin{array}{l}\text { Other CINEMA Başka is defined as a cinema/movie watching experience which has no equivalent in } \\
\text { Turkey. New to country, innovative in local context. There are similar practices in the world, but most } \\
\text { are limited with one theater. But also innovative in global scale as it represents a new model that can be } \\
\text { replicated to new contexts. Sinebebe (CineBaby) is again a unique experience, innovative in Turkey. }\end{array}$ \\
\hline
\end{tabular}




\section{Teyit.org - Verification.org (founded in 2016)}

Problem definition : disinformation on social media, lack of verification for news and shared content, social reactions based on these false news and disinformation

Results: Success - Google started to prioritize teyit.org analyses in the search results on 2016. Editor Gülin Çavuş was accepted for International Fact-Checking Network fellowship programme, Social media regulation offered by Teyit.org is accepted to be discussed in Parliament Assembly on 2016.

\begin{tabular}{|c|c|}
\hline Dimensions & Explanations \\
\hline Actors & $\begin{array}{l}\text { Founder / Reporter/ Editor M. A. Foça } \\
\text { Gülin Çavuş, Taha Onur Selimoğlu and } 11 \text { more volunteers } \\
\text { LAwyers, NEws Agencies, Search engines } \\
\text { British Embassy of Ankara } \\
\text { Istasyon Incubation TEDU Center for Social Innovation } \\
\text { European Endowment for Democracy (EED) Investor } \\
\text { SivilDüşün (Think civil) EU Programme PArtner } \\
\text { First Draft Partner } \\
\text { Ekşi Sözlük Partner }\end{array}$ \\
\hline $\begin{array}{l}\text { Processes and } \\
\text { collective } \\
\text { activities }\end{array}$ & $\begin{array}{l}\text { teyit.org is a verification platform that scans, choses, investigates suspicious information and delivers them } \\
\text { to readers by turning them into analyses. } \\
\text { Every single day, current news and trending topics on social media are checked via digital devices. At the } \\
\text { same time, the stories sent by readers, widespread false facts and urban legends are also in this category. A } \\
\text { software called Dubito helps the editors with social media scanning. The software is currently in beta } \\
\text { planned to be released as a open-sourced software. teyit.org will strive to deliver filtered information to } \\
\text { readers by verifying widespread false facts, trending doubtful news, the claims made by the mainstream } \\
\text { media and urban legends } \\
\text { online with the intent of ensuring that the citizens who use internet as a source of news and non- } \\
\text { governmental organizations have access to true information, encouraging people to think critically and to } \\
\text { have awareness about accessing true information. } \\
\text { teyit.org has been produced with the support of the European Endowment for Democracy (EED). Its } \\
\text { contents do not necessarily reflect the official opinion of EED. Responsibility for the information and } \\
\text { views expressed in this publication lies entirely with the author(s). } \\
\text { For teyit.org team to choose a particular content to investigate, the content must be viral, important enough } \\
\text { to cause life-threathining risks, possibly can create conflict. Also if there is a possibility of a delay in } \\
\text { evaluation causing same risks. We respect political diversity and the different worldviews of the team } \\
\text { members. But we do not allow any point of view to be effective on the verification processes. The } \\
\text { worldviews of the subcontractors are not effective in any analysis or any work done by teyit.org. teyit.org } \\
\text { employees can not be a member of any political party, can not take part in election campaigns. }\end{array}$ \\
\hline Social needs & $\begin{array}{l}\text { According to } 2015 \text { Digital News Report of Reuters Institute for the Study of Journalism, the country which } \\
\text { social media is the most popular news source is Turkey with } 67 \text { percent rate, among } 18 \text { countries. The } \\
\text { ranking of social networks as news sources, } 69 \text { percent of the participants from Turkey uses Facebook, } 33 \\
\text { percent of them uses Twitter, } 33 \text { percent Google+ and } 14 \text { percent of them uses YouTube. The number of } \\
\text { participants who stated that "I believe most of the stories I saw" is the lowest for Turkey. } \\
\text { In these days, the trust to media is eroding and polarization is deepening. teyit.org will verify the } \\
\text { suspicious content, publish analyze, contribute to critical thinking and quality news production. These } \\
\text { operations will minimize life threatening crisis and possibility of conflict. } \\
\text { teyit.org will strive to deliver filtered information to readers by verifying widespread false facts, trending } \\
\text { doubtful news, the claims made by the mainstream media and urban legends. }\end{array}$ \\
\hline $\begin{array}{l}\text { Social } \\
\text { improvements } \\
\text { or answers }\end{array}$ & $\begin{array}{l}\text { Delivering filtered information to readers by verifying widespread false facts, trending doubtful news, the } \\
\text { claims made by the mainstream media and urban legends } \\
\text { Social media regulation offered by Teyit.org is accepted to be discussed in Parliament Assembly on } 2016 \text {. } \\
11 \text { suspicious new application, teyit.org radar catches almost } 9 \text { news per day. Half of them are found to be } \\
\text { wrong. } \\
76 \% \text { of total analysed news were found to be wrong }\end{array}$ \\
\hline $\begin{array}{l}\text { Innovativenes } \\
\mathrm{s}\end{array}$ & $\begin{array}{l}\text { Innovative for } \\
\text { No unique newness in global scale as International Fact-Checking Network exists. However, as a social } \\
\text { enterprise and for the uniqueness of their developing country model with unique algorithms. }\end{array}$ \\
\hline
\end{tabular}




\section{Ustamdan.com - FromMyMaster.com (founded in 2013)}

Problem definition : lack of incubation and supporting platforms for social innovators

Results: Failure and success - Supported by the U.S. president Barack Obama and organized by the Obama administration, UStamdan initiative represented Turkey with 3 other successful Turkish women entrepreneurs in 2016. Opened a branch in ITU Teknokent San Francisco. Reached 16 different regions in 2017. 18 companies and NGOs who support as customers and sponsors. However revenues are not enough to create new business, mostly due to the delays in deliveries of products and order scheduling problems.

\begin{tabular}{|c|c|}
\hline Dimensions & Explanations \\
\hline Actors & $\begin{array}{l}\text { Founders } \\
\text { Handcraftsmen in Anatolia } \\
\text { Travel agencies and tourism companies } \\
\text { Ministry of Culture } \\
\text { Companies as sponsors and customers } \\
\text { ITU Teknokent } \\
18 \text { companies and NGOs who support as customers and sponsors }\end{array}$ \\
\hline $\begin{array}{l}\text { Processes and } \\
\text { collective } \\
\text { activities }\end{array}$ & $\begin{array}{l}\text { Ustamdan is a bridge constructed by product and writing to convey the culture and local effort to people } \\
\text { by bringing them together with creative ideas. At one side of this bridge, there are hands beating copper } \\
\text { and at other side, hands showing respect for labor. } \\
\text { Ustamdan team travels to Anatolia, meets artisan craftsmen in Anatolia and transfers their stories and } \\
\text { products to the internet environment via e-commerce project. While blogs revitalize the forgotten crafts } \\
\text { of Anatolia, e-commerce initiative meets hands-on, eye-catching products online with enthusiasm. } \\
\text { Provide local manufacture consultancy special for foreign and domestic corporations and offer the } \\
\text { process monitoring service. } \\
\text { Create a product selection for corporate gifts. Make employees feel special thanks to Ustamdan's unique } \\
\text { products. } \\
\text { Offers Cultural Content Management by collecting information from media and visits/interviews }\end{array}$ \\
\hline Social needs & $\begin{array}{l}\text { The Ustamdan.com initiative aims to increase the sustainability of local markets, to convey the historical } \\
\text { and cultural values of the regions to future generations, and to contribute to regional tourism by telling } \\
\text { business stories. In addition to this, it is to create additional income source for the masters of Anadol, } \\
\text { expanding the product market and indirectly providing them employment, strengthening the economies. }\end{array}$ \\
\hline $\begin{array}{l}\text { Social } \\
\text { improvements } \\
\text { or answers }\end{array}$ & $\begin{array}{l}\text { Active } 8 \text { masters and } 104 \text { products in the website in the end of } 1 \text { st year. Aims to add } 1 \text { master per month } \\
\text { and expand the product portfolio. } \\
\text { Total } 16 \text { regions hand crafts are included by } 2017 \text {. }\end{array}$ \\
\hline Innovativeness & $\begin{array}{l}\text { First platform in Turkey with advanced software and continous travelling of the founders. } \\
\text { Newness to country, innovative in local context. }\end{array}$ \\
\hline
\end{tabular}




\section{Yuvarla.com - Rollover (founded in 2014)}

Problem definition : lack of funding mechanisms for NGOs and social projects

Results: Success- Currently works with 15 different non-governmental organizations (NGOs). Yuvarla.com (Rollover) users have rolled over more than 600 pounds of spending and donated more than half a million TL to NGOs, Ashoka member of Change Maker Exchange Network, International Youth Foundation, entrepreneur local fellow: SAP sent 3 over talented employees for volunteer work in Yuvarla, Ambassador of Harvard University \& Massachusetts Institute of Technology for collaboration in social entrepreneurship, Bilgi Young Social Entrepreneurship REward, Sabanc1 Social Impact Forum Best Social Entrepreneurship"

\begin{tabular}{|c|c|}
\hline Dimensions & Explanations \\
\hline Actors & $\begin{array}{l}\text { Founders } \\
\text { Kolektif Hourse } \\
\text { Sabancı Social Impact Forum } \\
\text { Credit Cards Center (BKM) (Sponsor), İs Bank (Sponsor) } \\
\text { Buluşum (Supporter-for PR activities), Radore (Supporter for IT infrastructure) } \\
\text { Banks } \\
\text { Volunteers, Donators } \\
\text { Çözüm Kumbarası } \\
\text { Ashoka member, Internationall Young Foundation }\end{array}$ \\
\hline $\begin{array}{l}\text { Processes and } \\
\text { collective } \\
\text { activities }\end{array}$ & $\begin{array}{l}\text { The one who can ready to give his penny to the associations or foundations his/her has chosen from the } \\
\text { market exchange, restaurant expenditure, from the shirt you bought, to the joy of the fun, by rolling the } \\
\text { furrows of your card expenses to the next TL } \\
\text { For example; spending made from an e-commerce site was kept at } 76.90 \text { TL. You can donate } 15 \text { different } \\
\text { associations, foundations and civil society organizations (NGOs), including TEMA, Darüşşaka, } \\
\text { Kizılay, Unicef, ACEV, by TL } 0.10 \text { TL depending on your choice. This donation is charged directly to } \\
\text { the NGO without touching the "Yuvarla" } \\
\text { No need for Credit Card Nr (BKM verifies user limits); high security of personal information, SSL } \\
\text { encryption } \\
\text { NGOs must be an association that works for social value and benefitor must have official foundation } \\
\text { status legally, NGOs are natural partners. } \\
\text { NGOs are expected to share and publish their income and spendings financial tables in their web sites } \\
\text { (Must be transparent and be shared with yuvarla.com) } \\
\text { NGO must be recommended by at least } 5000 \text { active Yuvarla.com users to be included in the yuvarla } \\
\text { system (as donations are in kuruş (cent of TL) units, total amount of donations would not be meaningful } \\
\text { if the supporter nr in the system stays lower than 5000) }\end{array}$ \\
\hline Social needs & $\begin{array}{l}\text { Yuvarla, who carries the donation piggy bank to the store, donates donations to the associations and } \\
\text { foundations by rounding out the payments of the users' e-commerce sites }\end{array}$ \\
\hline $\begin{array}{l}\text { Social } \\
\text { improvements } \\
\text { or answers }\end{array}$ & $\begin{array}{l}\text { Currently works with } 15 \text { different non-governmental organizations (NGOs). Yuvarla.com (Rollover) } \\
\text { users rolled over more than } 600 \text { pounds of spending and donated more than half a million TL to NGOs }\end{array}$ \\
\hline Innovativeness & $\begin{array}{l}\text { It is the first social enterprise that takes Turkey's first social impact investment according to the literature. } \\
\text { Innovative for its business model for Turkey, and newness in the region as well. Local innovation with a } \\
\text { potential to be replicated to similar contexts. }\end{array}$ \\
\hline
\end{tabular}




\section{Fongogo.com (founded in 2013)}

Problem definition : lack of massive funding for social and entrepreneurial, cultural projects. Lack of financing mechanisms for cultural/intellectual products

Results: Success - At the end of 2014, Fongogo earned \$ 10,000 in the Intel Solution Combo competition and was ranked 10th in the Web Initiative of the Year at the 2014 Webrazzi Awards.

Till 2016, up to 94 projects have been published. With about 1,000 supporters, 26 of these projects have been successfully funded. Highest funding per project is $81.000 \mathrm{TL}$

\begin{tabular}{|c|c|}
\hline Dimensions & Explanations \\
\hline Actors & $\begin{array}{l}\text { Founders } \\
\text { Donators } \\
\text { Project owners/Artists/Social entrepreneurs(technological entrepreneurs/activists } \\
\text { Ambasadors/Volunteers } \\
\text { Catregory Leaders (Celebrities and businessman) } \\
\text { Individual Angels (Financers) } \\
\text { Corporate Angels } \\
\text { Supporters of the project }\end{array}$ \\
\hline $\begin{array}{l}\text { Processes and } \\
\text { collective } \\
\text { activities }\end{array}$ & $\begin{array}{l}\text { Anyone who has a project in any subject but need some capital support meet in this platform with whom } \\
\text { wants to give a support any project his/he likes } \\
\text { Fongogo is a marketplace that acts as a tool which enables the colectively raising fund that is needed to } \\
\text { implement all kinds of projects that some how creates social benefit and impact, by the support and } \\
\text { donations of the mass of people. } \\
\text { Massive funding is the name given to small amounts of investors who we call mass of ideas, projects and } \\
\text { companies. } \\
\text { Project owners submit the products and services of their projects to users in correspondence to their } \\
\text { supports. Fongogo provides the infratructure and facilities/tools/software that project owners can use to } \\
\text { create their project web sites and use their payment systems. } \\
\text { Up to now, up to } 94 \text { projects have been published. With about } 1,000 \text { supporters, } 26 \text { of these projects have } \\
\text { been successfully funded. }\end{array}$ \\
\hline Social needs & $\begin{array}{l}\text { In Turkey ecosystem for entrepreneur remained in an enclosed environment and therefore could not } \\
\text { make progress on the expected scale. }\end{array}$ \\
\hline $\begin{array}{l}\text { Social } \\
\text { improvements } \\
\text { or answers }\end{array}$ & $\begin{array}{l}\text { Till 2016, up to } 94 \text { projects have been published. With about } 1,000 \text { supporters, } 26 \text { of these projects have } \\
\text { been successfully funded. Highest funding per project is } 81.000 \mathrm{TL} \\
\text { With massive funding, masses will now be aware of this ecosystem; the ecosystem will develop at the } \\
\text { desired rate and spread and ideas will come to life. }\end{array}$ \\
\hline Innovativeness & $\begin{array}{l}\text { Fongogo Pro is the first capital-based massive funding platform of Fongogo, Turkey's leading massive } \\
\text { funding site. Innovative locally }\end{array}$ \\
\hline
\end{tabular}




\section{Zumbara - Time Moneybox (founded in 2010)}

Problem definition : lack of platforms and business models for gift culture and gift economy; lack of structures for generating trust based relationships and cooperating communities.

Results: Failure/success : For two years until July 2011, no professional services (Money) were used for Zumbara. In 2 years 2200 people exhanged 200 services in Zumbara. Among first 20 projects in Action Net Global Fellows Contest, Rewarded by MIT Enterprise Forum Türkey Business Plan Contest, Bilgi University Social Entrepreneurship program, Garanti Kagider Women Entrepreneurship Programme and E-Tohum."

\begin{tabular}{|c|c|}
\hline Dimensions & Explanations \\
\hline Actors & $\begin{array}{l}\text { Founder } \\
\text { Bilgi Social incubator } \\
\text { NGOs like KAGIDER } \\
\text { Companies like Garanti } \\
\text { Supporters, Volunteers } \\
\text { More than } 30 \text { persons give support the Zumbara }\end{array}$ \\
\hline $\begin{array}{c}\text { Processes and } \\
\text { collective } \\
\text { activities }\end{array}$ & $\begin{array}{l}\text { Zumbara is a community in which talents and experiences are shared, where time is used instead of } \\
\text { Money. } \\
\text { Zumbara is the abbreviation of Zaman Kumbaras1. It is an alternatif economic system platform that } \\
\text { allows people to earn hour in exchange of their service that they give. Today, after giving two hours } \\
\text { service, you can either take } 2 \text { hours service from one person or from two different people as one hour } \\
\text { from each. Or, if you wish, you can wait until another service option comes out that you would choose } \\
\text { instead } \\
\text { Zumbara is a social movement. Join us to be a part of this movement: } \\
1 \text { Help someone for } 1 \text { hour } \\
2 \text { Earn } 1 \text { hour in exchange } \\
3 \text { With this } 1 \text { hour, get another service from the community } \\
\text { combining Time Bank system and the interactive role created by the internet, at the same time using the } \\
\text { Time Bank system to create this combination itself. Namely, except programming, for the past two years } \\
\text { until July } 2011 \text {, no professional services (Money) were used for Zumbara. } \\
\text { Everything was realized by the effort of the beautiful people who believed in the idea, and wanted to } \\
\text { participate in it. }\end{array}$ \\
\hline Social needs & $\begin{array}{l}\text { Raising awareness about sharing ethos and gift economy, opening spaces for people so that they can } \\
\text { meet their needs by sharing their gifts ( knowledge, skills, experiences, time) and generating trust based } \\
\text { relationships and cooperating communities. } \\
\text { (the concept of "time" should be at the center of life, at the place where it belongs. To make lives easier } \\
\text { and more beautiful, generate healthy and secure communities when we spend time for each other, share } \\
\text { our knowledge, skills, talents and experiences with others.) }\end{array}$ \\
\hline $\begin{array}{c}\text { Social } \\
\text { improvements } \\
\text { or answers }\end{array}$ & $\begin{array}{l}\text { Except programming, for the past two years until July 2011, no professional services (Money) were used } \\
\text { for Zumbara. } \\
\text { In } 2 \text { years } 2200 \text { people exhanged } 200 \text { services in Zumbara (Foreign language practices, photograhpy } \\
\text { lesseons, web site development, art criticism, programming, etc. ) } \\
\text { Everything was realized by the effort of the beautiful people who believed in the idea, and wanted to } \\
\text { participate in it. }\end{array}$ \\
\hline Innovativeness & $\begin{array}{l}\text { Zumbara is the first project of the time bank with social media in Turkey. Innovative locally. } \\
\text { Time Bank system already exists in } 6 \text { continents, } 33 \text { countries including UK, USA, Israel, Spain, } \\
\text { Portugal, Italy, Curacao, Slovakia, South Korea, China, Japan, and Australia. This means that alternative } \\
\text { economy is a rapidly growing movement all around the world. Zumbara is an important part of this } \\
\text { movement. }\end{array}$ \\
\hline
\end{tabular}




\section{Iyi Babalar Platformu - Good Fathers Platform (founded in 2017)}

Problem definition : Parenting and diversity, family's lack of knowledge and skills for parenting

Results: Success -? (Short term outcomes) Father Support programme of AÇEV which is a 13 week adult training programme that aims to support fathers in child raising reached 82.500 fathers.

\begin{tabular}{|c|c|}
\hline Dimensions & Explanations \\
\hline Actors & $\begin{array}{l}\text { Founders } \\
\text { Anne Çocuk Eğitim Vakfi (AÇEV)NGO } \\
\text { Bilgi Social Incubator } \\
\text { Volunteer Parents } \\
\text { Trainers } \\
\text { Public Institutions } \\
\text { Local partnerships } \\
\text { Volunteers from academia and schools } \\
\text { Pedagogists }\end{array}$ \\
\hline $\begin{array}{l}\text { Processes and } \\
\text { collective } \\
\text { activities }\end{array}$ & $\begin{array}{l}\text { Solution-oriented, scientific, impartial and independent activities; sexist, political and discriminatory. } \\
\text { Meeting organizations } \\
\text { Campaigns } \\
\text { Trainings, workshops Seminars } \\
\text { Projects - Father Support Training Project } \\
\text { Father-Child Activities } \\
\text { Blogs }\end{array}$ \\
\hline Social needs & $\begin{array}{l}\text { The community gives very little information and skill support when they are parents. The role of the father } \\
\text { is often learned through trial and error, which can lead to serious mistakes in child rearing and unreliable } \\
\text { injuries. In today's world, it has become necessary for parents to be involved parents who are actively } \\
\text { involved in the care of children, warmly, reliably, and easily accessible, contributing significantly to all } \\
\text { areas of development of their children. } \\
\text { Contributing to the formation of societal consciousness about paternity, encouraging and coordinating the } \\
\text { willing parents for child development and education, and contributing to the development of resources for } \\
\text { paternity to develop, demand and develop child-rearing skills. }\end{array}$ \\
\hline $\begin{array}{l}\text { Social } \\
\text { improvements } \\
\text { or answers }\end{array}$ & $\begin{array}{l}85000 \text { father was trained in AÇEV trainings that lead to creation of platform. } \\
\text { Linkages between NGOs and public institutions and civil society built. } \\
\text { Promoted the idea in social seminars and meetings and took place in media. }\end{array}$ \\
\hline $\begin{array}{l}\text { Innovativenes } \\
\mathrm{s}\end{array}$ & $\begin{array}{l}\text { The first platform of developing consciousness of being a good father } \\
\text { Global innovation DNC platform in USA (with social policy actions) }\end{array}$ \\
\hline
\end{tabular}

By the dimensions derived from Table 3, (Dimensions of Social Innovation (Correia et al., 2017) somparisons of these projects as multiple case studies are represented in Table 4. As well comparative analysis of the cases by entrepreneurial characteristics are given in Table 5 below.

\section{CONCLUSION AND DISCUSSIONS}

In fields of social innovation practice and research, there is still high need for collecting cases in a comparative manner for providing inputs to road mapping and benchmarking processes of innovators and entrepreneurs who aim to introduce solutions for local problems.

Based on the comparative multiple case study analysis, this study aimed to contribute to the body of knowledge on social innovation practices in Turkey by analyzing them by their characteristics and by dimensions that are derived from theoretical background. As known, the main motivation of social innovation is to satisfy social needs caused by the absence of the Government or the Market, where SI initiatives are pointed as reactions to social problems by using local solidarity and reciprocity mechanisms that recognize new governance structures (Pisano, Lange, \& Berger, 2015). SI complements or utilize technological innovations in the regional, local or organizational settings (Freeman, 1988; Schumpeter, 1934; Drucker, 1985). Hence the cases are selected from those which intensely use ICT technologies (internet, mobile, e-commerce etc.) for digital components. 
Findings revealed that, for innovativeness dimension the majority of selected cases has innovative patterns in local context, which means their solutions are new to country, with a potential to be replicated in similar contexts. However their new-to-world characteristic is rare and their potential to globalize their embedded solutions is low (Table 4). Furthermore, they do not cover new institutional arrangements and structural rearrangements in societal level, hence their sustainability can only be provided by the continuous efforts of the founders, entrepreneurs and volunteers. Additionally, most of the cases do not cover training and creating skills in the society that is included in Processes and Collective Actions dimension. This attribute must be considered as critical in terms of sustainability of the solutions they offered. As well, the positive results of findings about the cases on Table 4- "Processes and Collective Action" dimension supported the acceptance of "H2: Processes and collective action became determinant in Success of Social innovations in Turkey".

In all attributes of Actors dimension, as can be seen from Table 4, most of the cases presents strong attributes. As a common strength that are observed in selected cases, Social Inclusion and Active Participation of participants, and Actors Role in Identifying Social needs can be considered.

\section{Table 4. Comparison of Selected Multiple Cases by Social Innovation Dimensions}

\begin{tabular}{|c|c|c|c|c|c|c|c|c|c|c|c|}
\hline Dimension & Success Factors & $\begin{array}{c}\begin{array}{c}\text { Oy ve } \\
\text { otesi }\end{array} \\
\end{array}$ & ihtiyaçharitası & $\begin{array}{l}\text { Açlk } \\
\text { radyo }\end{array}$ & $\begin{array}{l}\text { Baska } \\
\text { sinema }\end{array}$ & Teyitorg & $\begin{array}{c}\text { Ustamdan.co } \\
\mathrm{m}\end{array}$ & \begin{tabular}{|c|} 
Yuvarlaco \\
$\mathrm{m}$
\end{tabular} & \begin{tabular}{|c|}
$\begin{array}{c}\text { Fongogo.co } \\
\mathrm{m}\end{array}$ \\
\end{tabular} & Zumbaradan & $\begin{array}{l}\text { Iyi babalar } \\
\text { platformu }\end{array}$ \\
\hline \multirow{4}{*}{ Actors } & Synergy of actors & + & + & + & + & + & + & + & + & + & - \\
\hline & Motivation for innovation; & - & - & + & - & - & + & + & + & + & - \\
\hline & Strength to deal with obstacles; & + & + & + & + & + & - & + & + & + & - \\
\hline & $\begin{array}{l}\text { Availability to manage the resources to fix those } \\
\text { obstacles }\end{array}$ & + & + & + & + & + & - & + & + & - & - \\
\hline \multirow{5}{*}{$\begin{array}{l}\text { Processes and } \\
\text { collective } \\
\text { activities }\end{array}$} & Cooperation between the many actors involved & + & + & + & + & + & + & + & + & + & + \\
\hline & $\begin{array}{l}\text { Active participation of individuals/organizations } \\
\text { that represent this dimension }\end{array}$ & + & + & + & + & + & + & + & + & + & + \\
\hline & Social inclusion, & + & + & + & + & + & + & + & + & + & + \\
\hline & Training individuals and & + & - & - & - & + & + & - & - & - & + \\
\hline & $\begin{array}{l}\text { The idea of social change as a factor that can } \\
\text { transform the relations of power }\end{array}$ & + & - & + & + & - & + & - & + & + & \\
\hline \multirow[t]{2}{*}{ Social needs } & $\begin{array}{l}\text { Actors role in identifying social needs, to help to } \\
\text { solve social claims that are not articulated with } \\
\text { necessities and to cooperate with actors and } \\
\text { affected parties during the data collection phase. }\end{array}$ & + & + & + & + & + & + & + & + & + & + \\
\hline & $\begin{array}{l}\text { Structural modifications that occur due to the } \\
\text { search for social needs satisfaction, and those needs } \\
\text { can be qualified as incremental, radical or systemic }\end{array}$ & - & - & - & - & - & + & - & - & + & + \\
\hline \multirow{3}{*}{$\begin{array}{l}\text { Social } \\
\text { improvements } \\
\text { or answers }\end{array}$} & More effective than existing solutions & + & + & + & + & + & + & + & + & + & + \\
\hline & $\begin{array}{l}\text { Generate improvements in terms of results, } \\
\text { including living conditions, satisfaction levels, life } \\
\text { expectancy rates, reintegration into the labor } \\
\text { Market, improving welfare and social cohesion. It } \\
\text { intends to do more than to just solve a social issue, } \\
\text { it intends to provide answers to an aspiration. }\end{array}$ & + & + & - & - & - & + & + & - & - & + \\
\hline & $\begin{array}{l}\text { Cooperation Power of Civil Society } \\
\text { Active agent in search of solutions of social needes }\end{array}$ & + & + & + & - & + & + & + & + & + & + \\
\hline \multirow{4}{*}{ Innovativeness. } & $\begin{array}{l}\text { Implementation of new institutional arrangements } \\
\text { between actors and new social rules }\end{array}$ & - & - & - & - & - & + & - & + & - & - \\
\hline & $\begin{array}{l}\text { New solutions emerge as alternatives in the } \\
\text { implementation's initial phase, however, in long- } \\
\text { term, tend to be institutionalized, generating new } \\
\text { work, development, and governance models. }\end{array}$ & - & - & + & - & + & + & - & - & - & - \\
\hline & $\begin{array}{l}\text { Innovative character of the innovation process, } \\
\text { from the identification of social needs to the } \\
\text { implementation process, as well as the adaptation } \\
\text { to other contexts at the time of reapplication. All of } \\
\text { this development depends on the par ticipation of a } \\
\text { diversity of actors who act in a democratic fashion, }\end{array}$ & + & - & + & + & + & + & + & + & + & - \\
\hline & Collective action, allow replication & + & + & + & + & + & + & + & + & + & + \\
\hline
\end{tabular}


Journal of Global Strategic Management | V. 11 | N. 2 | 2017-December | isma.info | 077-100 | DOI: 10.20460/JGSM.2018.254

Table 5. Comparison of Selected Multiple Cases by Other Characteristics of Social Innovation

\begin{tabular}{|c|c|c|c|c|c|c|c|}
\hline No & Name & $\begin{array}{l}\text { Performa } \\
\text { nce }\end{array}$ & Type of Structure & Founder Type & $\begin{array}{l}\text { Funding } \\
\text { Tupe }\end{array}$ & $\begin{array}{l}\text { Incuba } \\
\text { ted } \\
(\mathrm{Y} / \mathrm{N})\end{array}$ & $\begin{array}{c}\text { Private Sector } \\
\text { / Industry } \\
\text { domination }\end{array}$ \\
\hline 1 & Oy ve ötesi & Success & Social Collective & $\begin{array}{l}\text { Innovators that } \\
\text { was affected by } \\
\text { the problem }\end{array}$ & Entrepreneur & $\mathrm{N}$ & $\mathrm{N}$ \\
\hline 2 & ihtiyaçharitası & Success & $\begin{array}{l}\text { Social } \\
\text { Entrepreneurship }\end{array}$ & $\begin{array}{l}\text { Innovators who } \\
\text { wanted to solve } \\
\text { the problem }\end{array}$ & Sponsored & $\mathrm{N}$ & Y \\
\hline 3 & Açık radyo & Success & $\begin{array}{l}\text { Social } \\
\text { Entrepreneurship }\end{array}$ & $\begin{array}{l}\text { Innovators who } \\
\text { are professional } \\
\text { in the area } \\
\text { Innovators who } \\
\text { are affected by } \\
\text { the problem }\end{array}$ & Sponsored & $\mathrm{N}$ & $\mathrm{N}$ \\
\hline 4 & Başka sinema & Success & $\begin{array}{l}\text { Social } \\
\text { Entrepreneurship }\end{array}$ & $\begin{array}{l}\text { Innovators who } \\
\text { are professional } \\
\text { in the area } \\
\text { Innovators who } \\
\text { are affected by } \\
\text { the problem }\end{array}$ & Entrepreneur & $\mathrm{N}$ & Y \\
\hline 5 & Teyit.org & Success & $\begin{array}{l}\text { Social } \\
\text { Entrepreneurship }\end{array}$ & $\begin{array}{l}\text { Innovators who } \\
\text { are professional } \\
\text { in the area } \\
\text { Innovators who } \\
\text { are affected by } \\
\text { the problem }\end{array}$ & Sponsored & $\mathrm{Y}$ & $\mathrm{N}$ \\
\hline 6 & Ustamdan.com & $\begin{array}{l}\text { Success/ } \\
\text { Failure }\end{array}$ & $\begin{array}{l}\text { First Social } \\
\text { Initiative, then } \\
\text { Social } \\
\text { Entrepreneurship }\end{array}$ & $\begin{array}{l}\text { Innovators who } \\
\text { wanted to solve } \\
\text { the problem }\end{array}$ & $\begin{array}{l}\text { Angel } \\
\text { Investors }\end{array}$ & $\mathrm{Y}$ & $\mathrm{N}$ \\
\hline 7 & Yuvarla.com & Success & $\begin{array}{l}\text { Social } \\
\text { Entrepreneurship }\end{array}$ & $\begin{array}{l}\text { Innovators who } \\
\text { wanted to solve } \\
\text { the problem }\end{array}$ & $\begin{array}{l}\text { Angel } \\
\text { Investors }\end{array}$ & $\mathrm{N}$ & $\mathrm{Y}$ \\
\hline 8 & Fongogo.com & Success & Social Inıtiative & $\begin{array}{l}\text { Innovators who } \\
\text { wanted to solve } \\
\text { the problem }\end{array}$ & $\begin{array}{l}\text { Angel } \\
\text { Investors }\end{array}$ & Y & $\mathrm{N}$ \\
\hline 9 & Zumbaradan & $\begin{array}{l}\text { Success/ } \\
\text { Failure }\end{array}$ & Social Inıtiative & $\begin{array}{l}\text { Innovators who } \\
\text { wanted to solve } \\
\text { the problem }\end{array}$ & Sponsored & $\mathrm{N}$ & $\mathrm{N}$ \\
\hline 10 & $\begin{array}{l}\text { İyi babalar } \\
\text { platformu }\end{array}$ & Success? & Social Inıtiative & $\begin{array}{l}\text { Innovators who } \\
\text { are professional } \\
\text { in the area } \\
\text { Innovators who } \\
\text { are affected by } \\
\text { the problem }\end{array}$ & Sponsored & $\mathrm{Y}$ & $\mathrm{N}$ \\
\hline
\end{tabular}

Therefore, based on the analysis of the findings in Table 4- "Actor" dimensions (which most cases showed positive $(+)$ results), "H1: Actors became determinant in Success of Social innovations in Turkey" and from Table 5- "Founder Type, Success, Sponsorship" dimensions, the hypotheses of "H1: Actors became determinant in Success of Social innovations in Turkey" is accepted.In Social Improvements dimension, all cases represented a solution that is better than existing solutions, which enabled us to identify as "social innovations" according to the last clause of Phills et al. (2008) for social innovation characteristics (a novel solution to a social problem that is more effective, efficient, sustainable, or just than existing solutions).

For entrepreneurial characteristics, we see that most of the selected SI cases were not dominated by private sector or industry, which makes them "civil society" initiatives (Table 5). Being incubated in a social incubator centre is widely utilized by the cases that were started in last 5 years, as these centers are very new and rare in Turkey. However, based on the total results that were provided from Table 5"Private Sector Support and investments" and "Incubated $(\mathrm{Y} / \mathrm{N})$ dimensions", we see that most of the cases are not supported by sector or incubators. Therefore "H3: Private sector support and investments, incubations became determinant in Success of Social innovations in Turkey” is rejected. 
Social innovation and social entrepreneurship linkage is widely discussed by researchers and practitioners, hence in these case studies we observed that the founders tend to name themselves as social entrepreneurs when they are and then as social initiative. Most of the projects in these cases were started and performed by people who are affected by the problem or by the ones who wanted to solve the problem, rather than the ones who are professionals or knowledgeable in the problem theme of the case. This finding also confirms the approaches of social innovation that were introduced by EU (2013) which are "multi-disciplinary and more integrated to problem solving than the single department or single profession solutions of the past"; "participative and empowering of citizens and users rather than 'top down', expert-led or demand-led rather than supply-driven".

It is seen that, SI practices in Turkey is muchly in need of deployment and continuity rather than being in search of higher levels of uniqueness or innovativeness in global scale.

\section{IMPLICATIONS}

As a result of the fact that social innovation and social entrepreneurship linkage is widely discussed by researchers and practitioners, findings that are derived from these case studies revealed that differing social innovation practices and social entrepreneurship cases is a challenging task, especially in developing country contexts. When local research and literature on social innovation and entrepreneurship is immature for a specific context, it is hard to recognize the borders between social projects, social enterprises and products/services which include social innovation. Therefore, we believe that this study can inspire and guide the researchers and practitioners in exploring and understanding the social innovation practices, as the case analysis in this study on social innovation and social entrepreneurship utilizes and practically adapts the dimensions that were derived from literature. Furthermore, the case studies presents the impact of the leader/founder on the success of social innovation practices. Hence, we believe that it is critically important to understanding the linkages between the success of social innovation practices and the motivations and leadership styles/traits of their leading practitioners/entrepreneurs/founders. This relationship occurs as a basic research question that needs to receive more attention and effort both from management scholars and from social innovation researchers. Due to the fact that most of the projects were started and performed by people who are affected by the problem or by the ones who wanted to solve the problem, social innovation research and practice should prioritize to understand the impact of bottom up approaches, co-creation and open innovation on the success of social innovations.

Though case study approach served as a practical method for providing insights to SI practices in local context, we hope to enhance in-depth analysis and extend the case studies by applying other qualitative research methods like etnography and grounded theory in future research. Furthermore, case study analysis can be accompanied by quantitative methods including surveys and bibliometric analysis.

But before that, a Social Innovation Map in Turkey is among our priorities in our research agenda to enhance and expand the knowledge base on SI cases in local context. Only then, detailed analysis of similarities and differences, as well as motivations and obstacles of SI in Turkey can be done. This kind of mapping would also act as a Social Innovation itself. 


\section{REFERENCES}

André, I.; Abreu, A. Dimensões e espaços da inovação social. Finisterra, XLI, n. 81, 2006, p. 121-141

Assogba, Y. A. (2010).Théorie systémique de l'action sociale et innovation sociale. Innovation sociale et développement des communautés, Alliance de recherche université-communauté.

Avelino, F. Wittmayer, J., Haxeltine, A., Kemp, R., O’Riordan, T., Weaver, P., Loorbach, D. and Rotmans, J. (2014) Game-changers and Transformative Social Innovation. The Case of the Economic Crisis and the New Economy, Transit working paper, Transit: EU SSH.2013.3.2-1 Grant agreement no: 613169

Besançon, E., Chochoy, N., \& Guyon, T. (2013). L'innovation sociale: Principes et fondements d'un concept. Editions L'Harmattan.

Bignetti, L. P. (2011). As inovações sociais: uma incursão por ideias, tendências e focos de pesquisa.Ciências Sociais Unisinos, 47(1).

Bouchard, C. (1999). Contribution à une politique de l'immatériel. Recherche en sciences humaines et sociales et innovations sociales. Conseil québécois de la recherche sociale, Groupe de travail sur l'innovation sociale, Quebec.

Caulier-Grice, J., Davies, A., Patrick, R., \& Norman, W. (2012). Defining social innovation. A deliverable of the project: "The theoretical, empirical and policy foundations for building social innovation in Europe"(TEPSIE), European Commission-7th Framework Programme, Brussels: European Commission, DG Research.

Cloutier, J. (2003). Qu'est-ce que l'innovation sociale? Montreal: Collection Études théoriques No ET0314, CRISES. Canada.

Correia, S. E. N.; Oliveira, V. M De, and Gomez, C. R. P. (2017). Dimensions of social innovation and the roles of organizational actor: the proposition of a framework. RAM, Rev. Adm. Mackenzie [online]. 2016, vol.17, n.6 , pp.102-133.

Cunha, J., Benneworth, P., \& Oliveira, P. (2015). Social entrepreneurship and social innovation: A conceptual distinction. In Handbook of Research on Global Competitive Advantage through Innovation and Entrepreneurship (pp. 616-639). IGI Global.

Drucker, P. F. (1985). Innovation and entrepreneurship practices and principles. AmaconEtzkowitz, H. (2002). The triple helix of university-industry-government: implications for policy and evaluation. Swedish Institute for Studies in Education and Research.

European Commission (EC) (2013). Guide to social innovation. Brussels.

European Union/The Young Foundation (2010). Study on Social Innovation, A paper prepared byr the Social Innovation eXchange (SIX) and the Young Foundation for the Bureau of European Policy Advisors, (Retrieved on 20/10/2017) https://youngfoundation.org/wp-content/uploads/2012/10/Study-onSocial-Innovation-for-the-Bureau-of-European-Policy-Advisors-March-2010.pdf

Freeman, C. (1988). Japan: A new national system of innovation. In G. Dosi, C.Freeman, R. Nelson, G. Silverberg, \& L. Soete (Eds.), Technical change andeconomic theory (pp. 330-348). London, England: Pinter.

Geels, F. W. (2013). The impact of the financial-economic crisis on sustainability transitions: Financial investment, governance and public discourse. Environmental Innovation and Societal Transitions, 6, 6795.

Goldenberg, M. (2004). Social Innovation in Canada: How the Non-profit Sector Serves Canadians--and how it Can Serve Them Better. Canadian Policy Research Network Incorporated.

Goldenberg, M., Kamoji, W., Orton, L., \& Williamson, M. (2009). Social innovation in Canada: An update. Ottawa, Canadian Policy Research Networks. 
Goodrick, D. (2014). Comparative Case Studies, Methodological Briefs: Impact Evaluation 9, UNICEF Office of Research, Florence.

Howaldt, J. \& Schwarz, M. (2010). Social Innovation: Concepts, research fields, and international trends, IMA/ZLW \& IfU, IMO International Monitoring (Vol 5)

Hubert, A. (coord.) et al. 2011. Empowering people, driving change: Social innovation in the European Union. Bureau of the European Policy Advisers, European Commission. DOI: http://dx.doi.org/10.2796/13155

Hulgård, L., \& Vieira Ferrarini, A. (2010). Inovação social: rumo a uma mudança experimental na política pública?. Ciências Sociais Unisinos, 46(3).

Klein, J. L., Tremblay, D. G., \& Bussières, D. R. (2010). Social economy-based local initiatives and social innovation: a Montreal case study. International Journal of Technology Management, 51(1), 121138.

Lassance, A.E. Pedreira, J.S. Tecnologias sociais e políticas públicas. In: BRASIL, Ministério da Ciência e Tecnologia (org). Tecnologia social: uma estratégia para o desenvolvimento. Fundação Banco do Brasil, p. 65-81, Rio de Janeiro, 2004.

Manzini, E. (2014). Making things happen: Social innovation and design. Design Issues, 30(1), 57-66.

Martinelli, F. (2012). Social Innovation or Social Exclusion? Innovating Social Services in the Context of a Retrenching Welfare State. In Franz Hans-Werner, Hochgerner Josef, Howaldt Jürgen (Eds.), Challenge Social Innovation (169-180). Berlin: Springer-Verlag

Moulaert, F., Martinelli, F., Swyngedouw, E., \& Gonzalez, S. (2005). Towards alternative model(s) of local innovation. Urban studies, 42(11), 1969-1990.

Mulgan, G., (2006). The Process of Social Innovation Tagore LLC, innovations / spring 2006

Mulgan, G., Tucker, S., Ali, R. \& Sanders, B. (2007), Social innovation: what it is, why it matters and how it can be accelerated, Working Paper, Skoll Centre for Social Entrepreneurship, Oxford.

Nicholls, A., \& Murdock, A. (2012). The nature of social innovation. In Social innovation (pp. 1-30). Palgrave Macmillan UK.

Nicholls, A., Simon, J., Gabriel, M., \& Whelan, C. (Eds.). (2015). New frontiers in social innovation research. Springer.

Nilsson, W. O. (2003). Social innovation: An exploration of the literature. White paper for the McGillDupont Social Innovation Initiative.

PEREZ, Carlota. The new technological revolution. In: Presentation at the Technology Frontiers Forum of The Economist. 2013. p. 5.

Phills, J.A.; Deiglmeier, K \& Miller, D.T. 2008. Rediscovering Social Innovation, Stanford Social Innovation Review, Fall: 43.

Phillips, W., Lee, H., Ghobadian, A., O’Regan, N., \& James, P. (2015). Social innovation and social entrepreneurship: A systematic review. Group \& Organization Management, 40(3), 428-461.

Pisano, U., Lange, L., \& Berger, G. (2015). Social Innovation in Europe. An overview of the concept of social innovation in the context of European initiatives and practices. ESDN Quarterly Report, 36, 1-25.

Pol, E., \& Ville, S. (2009). Social innovation: Buzz word or enduring term?. Journalof Socio-Economics, 38(6), 878-885. doi:10.1016/j. socec.2009.02.011

Sandeep, M. S., \& Ravishankar, M. N. (2015). Social innovations in outsourcing: an empirical investigation of impact sourcing companies in India. The Journal of Strategic Information Systems, 24(4), 270-288. 
Saucier, C. et al. (2006). Développement et territoire. In J.-L. Klein \& D. Harrisson (Eds.).L’innovation sociale. Émergence et effets sur les transformations des sociétés (chapitre 19, pp. 377-395).Québec: Presses de l’Université du Québec.

Schumpeter, J. (1934). Capitalism, socialism, and democracy.

Sharra, R., \& Nyssens, M. (2010). Social innovation: An interdisciplinary and critical review of the concept. Université Catholique de Louvain Belgium, 1-15.

Sözen, M. and Tutal, E., (2016). Social Innovation in Turkey, EU Commission, http://sie_2016.testing.effusion2.dh.bytemark.co.uk/it/social-innovation-turkey

Urama, K. C. and Acheampong, E. (2013). Social innovation creates prosperous societies. Unleashing Breakthrough Innovation in Government, 9-11.

Tardif, C., \& Harrisson, D. (2005). Complémentarité, convergence et transversalité: la conceptualisation de l'innovation sociale au CRISES (No. 513). Crises.

Yıldırım, H.H (2016). Ar-Ge Reform Paketinin Düşündürdükleri: Sosyal İnovasyon, Sosyal Girişimcilik ve Sosyoteknokentler, Sağlık ve İnsan / Mart 2016/5. http://saglikveinsandergisi.com/wpcontent/uploads/2016/05/Analiz-51-1.pdf

Yin, R. K. (2002). Applications of Case Study Research Second Edition (Applied Social Research Methods Series Volume 34).

Young, H. P. (2011). The dynamics of social innovation. Proceedings of the National Academy of Sciences, 108(4), 21285-21291. 